\title{
Usefulness of Dermoscopy to Provide Accurate Assessment of Skin Cancers
}

\author{
Anna Michalak-Stoma (D) \\ Katarzyna Małkińska² \\ Dorota Krasowska (D) \\ 'Department of Dermatology, Venereology \\ and Paediatric Dermatology, Medical \\ University of Lublin, Lublin, 20-080, Poland; \\ ${ }^{2}$ Department of Dermatology, Venereology \\ and Paediatric Dermatology, Samodzielny \\ Publiczny Szpital Kliniczny No I, Lublin, 20- \\ 080, Poland
}

\begin{abstract}
Seborrheic keratosis (SK) is the most common benign tumour of epidermal origin. In most cases, it is simple to recognize in the clinical examination. However, sometimes SK can be a problematic lesion. We present the cases of two patients with seborrheic keratosis in whom we diagnosed the skin cancer through dermoscopic and histopathological examinations. The article aims to draw attention to the need for dermoscopic examinations to be included for an accurate assessment of the nevi not only by dermatologists but also notspecialized doctors. We would like to underline that many skin cancers share the similar features of malignancy, and competence and capability to interpret the dermoscopic pictures correctly are important for early recognition of malignant lesion. Very often malignant skin cancers can be hidden among benign lesions like seborrheic keratosis or they can be imitators of benign lesions. Amongst all cases of imposing SK, basal cell carcinoma, squamous cell carcinoma, melanoma is the most important differential diagnosis, of which their dermoscopic features will be discussed in this article.
\end{abstract}

Keywords: dermoscopy, seborrheic keratosis, skin cancer, melanoma, basal cell carcinoma, BCC, squamous cell carcinoma, SCC, Merkel-cell carcinoma, MCC, dermatofibrosarcoma protuberans, DFSP

\section{Introduction}

Seborrheic keratosis (SK) is the most common benign tumours of epidermal origin. SK is very simple to recognize in most cases in the clinical examination. However, patients and not-specialized doctors are worried frequently about these lesions, especially if the SK is irritated. In such cases, it is necessary to consult the lesion with a dermatologist and perform a dermoscopic examination. In a situation where there is a lot of SK lesions, one should be very vigilant not to overlook malignant lesions.

The aetiology is not fully understood. SK may be the result of the clonal expansion of mutated keratinocytes. ${ }^{1}$ The expression of the B-cell CLL/lymphoma 2 (BCL2), an oncogene that suppresses apoptosis, is low in SK compared to high values in basal (BCC) and squamous cell carcinoma (SCC). ${ }^{2}$ In over $80 \%$ of seborrheic keratosis at least one mutation was found and in $45 \%$ more than one mutation in oncogenes, for example in genes for fibroblast growth factor receptor 3 (FGFR3), phosphatidylinositol-4,5-bisphosphate 3-kinase catalytic subunit alpha (PIK3CA), Kirsten rat sarcoma 2 viral oncogene homolog (KRAS) or epidermal growth factor receptor (EGFR). ${ }^{3}$ SK has a higher keratinocyte proliferation rate and more inhibited apoptosis compared to healthy skin. ${ }^{4}$ Endothelin 1 stimulates DNA synthesis and melanogenesis in SK with increased pigmentation. ${ }^{5}$
Correspondence: Anna Michalak-Stoma Department of Dermatology, Venereology and Paediatric Dermatology, Medical University of Lublin, Staszica 16 Street, Lublin, 20-080, Poland Email annamichalak@wp.pl 
The incidence of seborrheic keratosis increases with age. Risk factors include: exposure to sunlight, older age and genetic predisposition. Most often the lesions appear on the trunk, less often on the face, neck and proximal parts of the limbs. Clinical features vary depending on the stage of development. Early SK is a small, light brown, sharply circumscribed patch. As the lesions develop, they become more haughty, dark in colour and the surface is uneven (papillary with horny masses). Seborrheic keratosis can be easily irritated due to its morphology and size. ${ }^{6,7}$

Seborrheic keratosis should be differentiated from melanoma, squamous cell carcinoma (SCC), basal cell carcinoma (BCC), extramammary Paget's disease, common warts and acanthosis nigricans. Histopathological examinations should be performed mainly in atypical clinical manifestations: in SK with ulceration and cresting. Other features that require patients' and physicians' attention are erosion, haemorrhages, modification and evolution in the macroscopic characteristics, and local erythema and pruritus. ${ }^{6-8}$

In general, the association between SK and malignant skin tumours appear to be incidental, but in situ tumour transformations occur more frequently in areas exposed to the sun and in immunocompromised patients. ${ }^{6}$

\section{Objective}

We present the cases of two patients with seborrheic keratosis in whom we diagnosed the skin cancer thanks to dermoscopic and histopathological examinations. The article aims to draw attention to the need for accurate assessment of nevi, including dermoscopy, not only by dermatologists but also not-specialised doctors. We summarised the dermoscopy features of the most common skin cancers to provide accurate assessment of skin lesions. We would like to underline that many skin cancers share the similar features of malignancy, and competence and capability to interpret the dermoscopic pictures correctly are important for early recognition of malignant lesion. Very often malignant skin cancers can be hidden among benign lesions like SK or they can be imitators of benign lesions. One should also always pay attention to nevi, even if the patient comes to see the doctor with another dermatological problem.

\section{Case Presentation I}

An 83-year-old male patient was referred to the outpatient clinic of the Department of Dermatology, Venereology and Paediatric Dermatology of the Medical University of Lublin by a family doctor due to generalized itching of the skin lasting for about six months. Additionally, the patient reported intensive exposure to ultraviolet (UV) radiation throughout his life. He was a marine radio navigator and spent a lot of time outdoors, he loves sunbathing and he has never used photoprotection.

During the clinical examination, numerous SK and solar lentigines were found on his trunk, as well as papules and excoriations (Figure 1A). In the area of the left scapula, a suspicious lesion of unknown duration was found - a nodule with an inflamed infiltrated margin, with ulceration, covered with horny and bloody masses (Figure 1B). The patient was diagnosed with scabies based on clinical and dermoscopic examination (positive triangle sign). The treatment with $5 \%$ permethrin gave relief to pruritus. The dermoscopic examination also confirmed the diagnosis of seborrheic keratosis with characteristic fingerprint-like structures, the presence of comedo-like openings and milia-like cysts (Figure 1C). In contrast, the dermoscopic image of the lesions in the area of the left scapula revealed asymmetry of structures, with ulceration in the upper pole, grey-blue veil, polymorphic vessels, and irregularly distributed brown globules and streaks. The dermoscopic picture was blurred by the powder the patient had used on the ulceration (Figure 1D). After a clinical and dermoscopic assessment, the patient was referred for complete excision with suspected melanoma/pigmented BCC. The suspicious lesion was totally removed and histopathologically examined. The result was basal ulcerative pigmentary carcinoma with total excision. A systematic follow-up for recurrence every 3 months is a further procedure for such a diagnosis.

\section{Case Presentation 2}

A 58-year-old female patient was referred to the outpatient clinic of the Department of Dermatology, Venereology and Paediatric Dermatology of the Medical University of Lublin by a family doctor due to extensive pigmentation on the right cheek. On examination, a hyperpigmented patch with 3 hyperkeratotic papules was observed. In the upper part of the patch, irregular hyperpigmentation was noted (Figure 2A). The patient reported she had had these lesions for many years and did not notice any difference in their appearance. In dermoscopy, the light brown structureless areas and fingerprint-like areas were found (Figure 2B). We also noticed the features of seborrheic keratosis in the papules (Figure 2C). In the upper part of the hyperpigmented patch, there was pigment located 

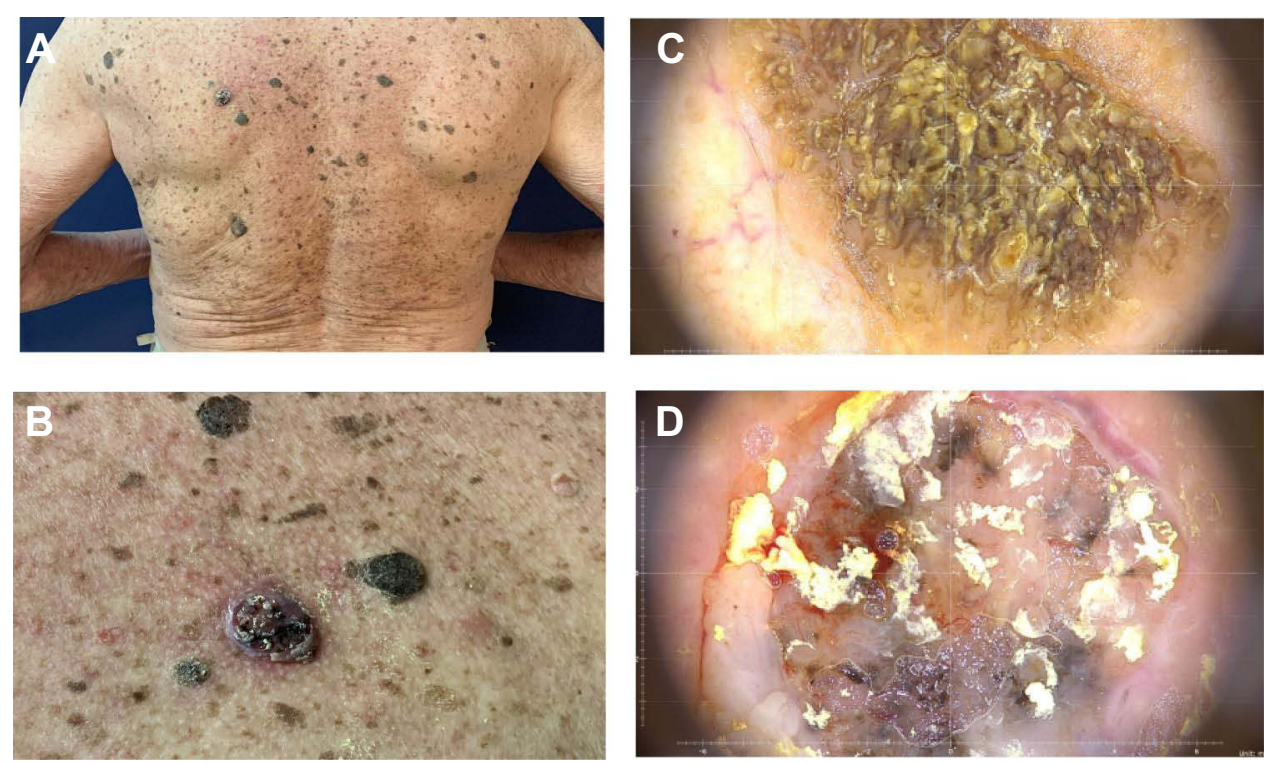

Figure I Case presentation I. (A) clinical presentation, (B) clinical presentation, detailed view of the suspected lesion, (C) dermoscopic picture of seborrheic keratosis, (D) dermoscopic picture of the pigmented BCC.
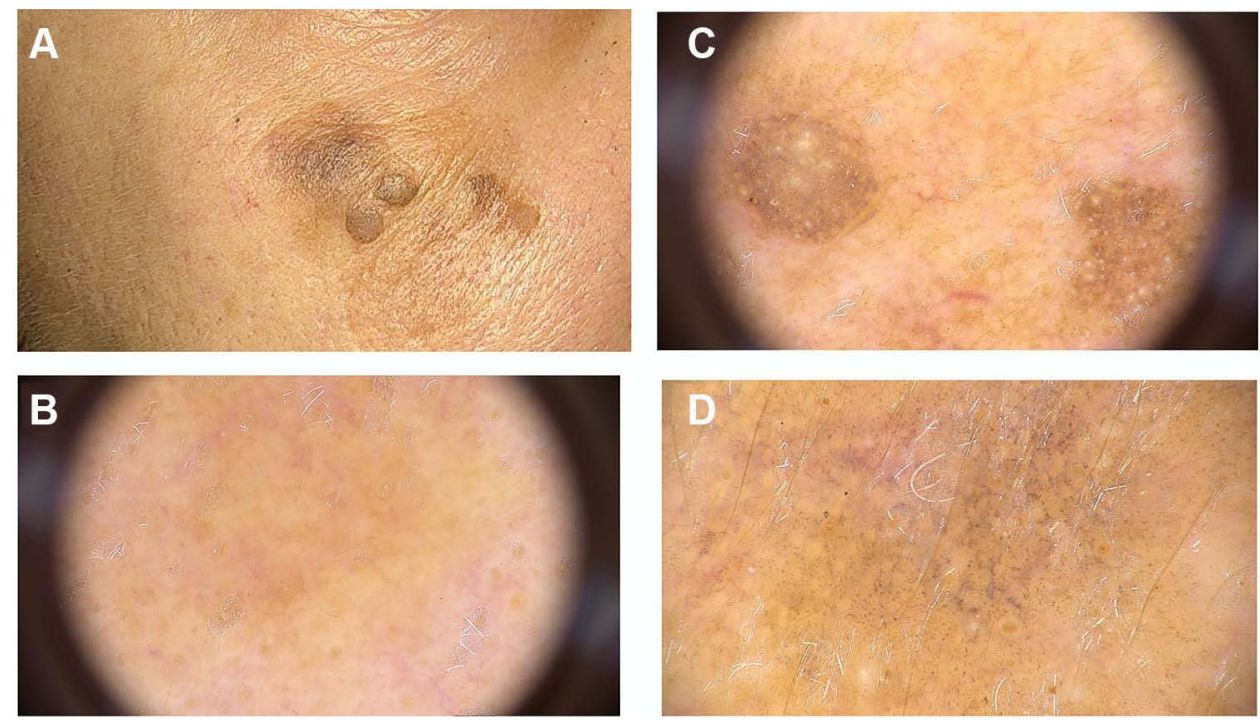

Figure 2 Case presentation 2. (A) clinical presentation, (B) dermoscopic picture of solar lentigo, (C) dermoscopic picture of seborrheic keratosis, (D) dermoscopic picture of the lentigo malignant melanoma.

around hair follicles in a symmetric pattern, however, some follicles were asymmetrically pigmented. In some parts of the lesion, we also noticed the pigment of a greyish hue and thus the patient was referred for a biopsy excision of a skin fragment of the upper part of this hyperpigmented patch (Figure 2D). A $1.3 \times 0.6 \times 0.4 \mathrm{~cm}$ skin fragment was cut out. In histopathology, melanoma from lentigo maligna was found, a lesion present in seborrheic keratosis.

\section{Dermoscopy}

Dermoscopy is a commonly used diagnostic method that enables non-invasive lesion assessment on skin, scalp, mucous membranes, nail plates and nail folds. Current types of equipment allow observations up to 10x magnification, but through the use of video-dermoscopy larger magnification may be acquired and archived to monitor further developments. ${ }^{9}$ Nowadays the dermoscopy is used not only for melanocytic lesion assessment to improve 
melanoma detection but also to diagnose and differentiate inflammatory, vascular, collagen and infectious skin diseases.

Dermoscopy increases the sensitivity of detecting malignant skin tumours and reduces the percentage of benign lesions being removed. Despite the development of other non-invasive diagnostic methods with better resolution, such as confocal microscopy or optical coherence tomography, dermoscopy remains a method that is widely available, accurate, fast and relatively easy to perform. ${ }^{10}$

Despite having a better knowledge of dermoscopic images of various skin lesions, there are often diagnostic doubts. Incorrect qualification of the lesion may have adverse consequences for the patient, especially if it turns out to be a malignant tumour. Therefore, all dermoscopic scales should focus on the greatest possible sensitivity in detecting potentially malignant lesions. In doubtful cases, the excision biopsy with a histopathological assessment of the lesion is decisive. ${ }^{11}$

Benign tumours which often have features suggesting potentially malignant nature in dermoscopy are: SK (including irritated, regressive, clonal SK), solar lentigo, melanoacanthoma, angiomas (mainly angiokeratoma and thrombosed angioma), dermatofibroma, benign adnexal tumours and nevi (Clark, Spitz, recurrent, combined, sclerosing). ${ }^{11}$

Malignant tumours that imitate benign lesions are melanoma (in situ, nevoid, spitzoid, verrucous, regressive, amelanotic), SCC (mainly well differentiated), and rarely BCC (non-pigmented variants). ${ }^{11}$

\section{Seborrheic Keratosis (SK)}

Dermoscopy of seborrheic keratosis shows very characteristic structures (Table 1). ${ }^{7,11-19}$ These structures are different in polarized or non-polarized light. Structures such as comedo-like openings, milia-like cysts, sharp demarcation are better visible in non-polarized light. In polarized light, it is easier to observe vessels such as hairpin vessels, dotted vessels, glomerular vessels, moth-eaten border, fingerprint-like structures and colour variability. It is worth using both types of light to achieve the best assessment of lesions. However, in some subtypes of SK, the features described above may be absent. ${ }^{10,11}$

Reticular SK and lentigo solaris may be improperly classified as a nevus or melanoma, especially when the network-like structure is asymmetrical or unevenly pigmented. In the lentigo solaris and reticular seborrheic keratosis, the characteristics of the network are: thinner lines, larger holes and sharp ends, without fading out of the network. ${ }^{11}$

Melanoacanthoma is a variant of seborrheic keratosis with an intensified pigment component. The dermoscopic image may improperly suggest malignant tumour growth. Intense pigmentation may impede visualization of structures typical for SK. In highly pigmented lesions, it should always be remembered that melanomas and other malignant skin neoplasms may have seborrheic papillary features and that malignant skin neoplasms may coexist with SK. ${ }^{11,17}$

Another type that may suggest tumour growth is lichen planus-like keratosis (LPLK). LPLK usually disappears spontaneously, and dermoscopic features change with the development or regression of the lesion. Watanabe et al assessed the variability of LPLK dermoscopic image over time. Based on this analysis, LPLK evolution stages have been proposed 1) pre-existing solar lentigo, 2) early inflammatory stage, 3) early regressing stage, 4) regressing stage and 5) late regressing stage. ${ }^{19}$ The most frequently mentioned dermoscopic features are light brown or grey pseudonetwork and blue-grey dots. The presence of scales, orange and dotted vessels in dermoscopy has also been described. ${ }^{19,20}$ LPLK in the middle or later stage loses the characteristic dermoscopic features of the solar lentigo or seborrheic keratosis and one may observe irregular dots or globules, irregular streaks or rhomboidal structures suggesting lentigo maligna. The differentiation between LPLK and lentigo maligna is crucial, careful observation of the lesion and biopsy should be performed when necessary. ${ }^{19}$ Sisti et al also reported a case where LPLK clinically masked amelanotic melanoma in situ. The pinkish background hue and polychromatic fine scales were the only suspicious features in dermoscopy. However, typical dermoscopic images for melanoma or SK were not present. LPLK was likely induced by melanoma cells as an inflammatory reaction. $^{21}$

A peculiar SK variant is clonal SK. This is a rare type of seborrheic keratosis, usually pigmented and it is clinically difficult to distinguish it from ordinary SK. Dermoscopy shows different sizes and irregularly distributed brown and blue-grey globules. Blue-grey structures are similar to irregular globules in melanoma or ovoid nests of BCC. The presence of sharp demarcation at the periphery or specific structures, eg, milia-like cysts, might help to recognize $\mathrm{SK} .^{7,11,17,18}$ 
Table I Dermoscopic Features of Seborrheic Keratosis

\begin{tabular}{|c|c|c|}
\hline Disease & Characteristic Dermoscopic Structures & References \\
\hline Seborrheic keratosis (SK) & $\begin{array}{l}\text { - Moth-eaten borders } \\
\text { - Hairpin vessels } \\
\text { - Brain-like structures } \\
\text { - Fingerprinting-like structures } \\
\text { - Comedo-like openings } \\
\text { - Milia-like cysts }\end{array}$ & {$[7,12-14]$} \\
\hline Irritated SK & $\begin{array}{l}\text { - Lack of the typical SK-related features } \\
\text { - Symmetric distribution of structures (vessels surrounded by halos) } \\
\text { - Vessels of various morphologies (hairpin, glomerular, tortuous) }\end{array}$ & {$[11,14,15]$} \\
\hline Melanoacanthoma & $\begin{array}{l}\text { - Heavily pigmented } \\
\text { - "Starburst" pattern } \\
\text { - Ridges and fissures } \\
\text { - Comedo-like openings } \\
\text { - Milia-like cysts } \\
\text { - Blue-white veil }\end{array}$ & {$[14,16]$} \\
\hline Clonal SK & $\begin{array}{l}\text { - Sharp demarcation } \\
\text { - Milia-like cysts } \\
\text { - Irregularly distributed brown and blue-grey globules }\end{array}$ & {$[7,11,14,17,18]$} \\
\hline LPLK/solar lentigo & - Light-brown pseudonetwork & {$[14,19]$} \\
\hline LPLK/ regression & $\begin{array}{l}\text { - Annular granular structures } \\
\text { - Grey pseudonetwork } \\
\text { - Blue-grey fine dots } \\
\text { - Irregular streaks } \\
\text { - Rhomboid structures }\end{array}$ & {$[14,19]$} \\
\hline
\end{tabular}

Abbreviations: SK, Seborrheic Keratosis; LPLK, Lichen Planus Like Keratosis.

\section{Non-Melanoma Skin Cancers (NMSC)}

\section{Basal Cell Carcinoma}

Basal cell carcinoma (BCC) is a slowly growing, malignant skin cancer. This is the most common malignant neoplasm in humans. A steady increase in the incidence of BCC is observed (on average $10 \%$ every 10 years). The peak incidence is observed in the 6-8th decade of life. ${ }^{22}$ Risk factors include genetic and environmental factors, like skin phototype (I-II), exposure to UV radiation, ionizing radiation, arsenic, polycyclic aromatic hydrocarbons, and chronic immunosuppression. ${ }^{23,24} \mathrm{BCC}$ is the most commonly observed on the face above the lines connecting the angles of the lips with the earlobes ( $80 \%$ of cases), especially on the nose. Lesions are less common on the lower part of the face, scalp or upper torso ( $15 \%$ of cases). Unusual areas of BCC have also been described, such as axillary, breast, anogenital, palms and soles. ${ }^{24,25}$
BCC clinical types are: nodular, superficial, infiltrative, morpheaform and ulcerative. Ulcerative BCC always requires histopathological confirmation because of its clinical similarity to other skin cancers or metastases (eg, thyroid cancer or kidney cancer).

Histopathological examination is required to confirm BCC. ${ }^{26}$ BCC histological division is based on the way of dermal infiltration. According to NCCN Clinical Practice Guidelines in Oncology (NCCN Guidelines ${ }^{\circledR}$ ) of Basal Cell Skin Cancer (Version 2.2021, February 25, 2021) there are two groups of BCC: low- and high-risk. Lowrisk histologic subtypes include nodular, superficial, and other non-aggressive growth patterns such as keratotic, infundibulocystic, and fibroepithelioma of Pinkus. Highrisk BCCs include basosquamous, infiltrative, sclerosing/ morpheaform, micronodular, and BCC with carcinosarcomatous differentiation. It can be also the mixed subtype. ${ }^{27}$

The relationship between the BCC histological type and the site of occurrence has been described. The 
Table 2 Differential Diagnosis of Basal Cell Carcinoma ${ }^{26}$

\begin{tabular}{|l|}
\hline Differential Diagnosis of Basal Cell Carcinoma \\
\hline Actinic keratosis \\
Bowen's disease \\
Seborrhoeic keratosis \\
Dermatomycosis \\
Nummular eczema \\
Psoriasis \\
Discoid lupus erythematosus (DLE) \\
Scar \\
Lupus vulgaris \\
Cutaneous adnexal neoplasms originating in: \\
- Hair follicles \\
- Sebaceous glands \\
- Sudoriparous glands \\
Amelanotic melanoma \\
\hline
\end{tabular}

superficial type was most frequently found in areas not exposed to sunlight, mainly on the torso, while the nodular type was most often found on the face. ${ }^{25}$ In NCCN Clinical Practice Guidelines in Oncology (NCCN Guidelines ${ }^{\circledR}$ ) of Basal Cell Skin Cancer, the initial presentation of regional or distant metastatic disease was distinguished. Metastatic BCC is very rare with a reported incidence between $0.00281 \%$ and $0.05 \% .{ }^{22,27}$

Many diseases should be included in the differential diagnosis of basal cell carcinoma (Table 2). ${ }^{26}$ The most characteristic dermoscopic features of $\mathrm{BCC}$ are described in Table 3. ${ }^{12,26,28-31}$

Non-pigmented BCC may be improperly classified as a dermal nevus. Especially in the case of the high pressure applied during a dermoscopic examination, compression of large vessels may occur. Then, characteristic arborizing vessels are invisible, and numerous short curved lines, so-called "comma vessels" of dermal nevus are present. In the case of dermoscopic examination of nodular lesions, polarized light (non-contact) dermoscopy is indicated. ${ }^{11}$ The second type of BCC that may cause diagnostic difficulties is pigmented BCC with a strongly intensified pigment component. Numerous, pigmented basaloid nests can cause diffuse blue pigmentation, imitating the pattern of blue nevi. However, unlike BCC, the blue nevus is a stable, longstanding lesion. ${ }^{11}$

Other methods helpful in the diagnosis and assessment of BCC staging include: reflectance confocal microscopy, optical coherence tomography and skin ultrasound.

\section{Squamous Cell Carcinoma}

Squamous cell carcinoma (SCC) is the second most common skin cancer right after basal cell carcinoma. In total, BCC and SCC account for $99 \%$ of all non-melanoma skin cancers (NMSCs). Squamous cell carcinoma is slowgrowing cancer that metastasizes to regional lymph nodes and distant organs. The risk of metastasis is about $4 \%$. However, patients receiving immunosuppressive treatment are at particularly high risk of SCC (60 to 150-fold) and other rare and aggressive skin cancers, like basosquamous cell carcinoma and Merkel-cell carcinoma. ${ }^{26,32}$ SCC is derived from keratinizing cells of the spinous epidermal layer. The number of sunburns, especially in childhood, chronic exposure to UV radiation and the total accumulated dose of solar radiation correlate with the development of SCC. According to studies by Manfredini et al the head and neck area was the most common localization of SCC, the next most common locations are limbs and torso. ${ }^{33}$ On the head, SCC is commonly observed around the nose, on the auricle, on the lower lip, on a frontalparietal area of men with androgenetic alopecia and on the dorsum of hands. ${ }^{32}$ SCC can also develop on the mucosa or the skin borders.

Actinic keratosis (AK) is a common condition preceding the development of SCC. AK occurs most often in people with skin phototype I and II according to Fitzpatrick's classification, especially in men. AK can be located on the top of the head, on the forehead, nose, auricles, dorsum of hands and on forearms. ${ }^{34}$ Usually there are numerous hyperkeratotic patches or papules on the sun-damaged skin. There are 3 clinical AK grades, which correspond to three dermoscopic patterns. The most characteristic features are described in Table 4. ${ }^{35}$

The clinical presentation of SCC depends on location. On the skin, it is an erythematous-exfoliative, erythematous-infiltrative well-limited lesion with superficial keratosis, a tumour or nodule with central keratinous masses, or a nodule with ulceration. On mucous membranes, SCC is an infiltrative, papillary or ulcerative, non-healing lesion with bulged edges. ${ }^{32}$

The SCC differential diagnosis is shown in Table $5{ }^{32}$ The SCC differentiation should include keratoacanthoma (KA). This is a common, low-grade tumour originating from hair follicles, microscopically very similar to SCC. It is characterized by rapid growth over several weeks or months, followed by spontaneous regression within 4-6 months in most cases, but it can rarely develop into 
Table 3 Dermoscopic Features of Basal Cell Carcinoma and Basal Squamous Cell Carcinoma

\begin{tabular}{|c|c|c|}
\hline Disease & Characteristic Dermoscopic Structures & References \\
\hline Superficial BCC & $\begin{array}{l}\text { - Shiny white-red structureless areas } \\
\text { - Short fine telangiectasia } \\
\text { - Maple leaf-like areas } \\
\text { - Multiple small erosions }\end{array}$ & {$[26,29]$} \\
\hline $\begin{array}{l}\text { Superficial BCC } \\
\text { (pigmented) }\end{array}$ & $\begin{array}{l}\text { - Maple leaf-like areas } \\
\text { - Spoke-wheel areas } \\
\text { - Brown concentric structures }\end{array}$ & {$[26,29]$} \\
\hline $\begin{array}{l}\text { Nodular BCC (non- } \\
\text { pigmented) }\end{array}$ & $\begin{array}{l}\text { - Large arborizing vessels } \\
\text { - Large central ulceration } \\
\text { - Glittering white lamellae and glittering streaks }\end{array}$ & {$[26,29]$} \\
\hline $\begin{array}{l}\text { Nodular BCC } \\
\text { (pigmented) }\end{array}$ & $\begin{array}{l}\text { - Large arborizing vessels } \\
\text { - Grey and blue ovoid nests } \\
\text { - Grey and blue granules and bodies } \\
\text { - Spoke-wheel areas } \\
\text { - Maple leaf-like areas }\end{array}$ & {$[26,29]$} \\
\hline Infiltrative BCC & $\begin{array}{l}\text { - White-red or yellow-red structureless background } \\
\text { - Arborizing vessels (scattered and thin, with less pronounced ramifications) } \\
\text { - Multiple blue-grey dots and blue-grey ovoid nests } \\
\text { - "Stellate pattern" - vessels, white lines or skin folds radiating from the peripheral margin of the } \\
\text { tumour into the surrounding skin }\end{array}$ & {$[26,29]$} \\
\hline Morpheaform BCC & $\begin{array}{l}\text { - Porcelain white glittering background } \\
\text { - Numerous fine arborizing vessels of a small caliber and less tendency to branch into finer } \\
\text { capillaries } \\
\text { - Shiny white-red structureless areas }\end{array}$ & {$[26,29]$} \\
\hline $\begin{array}{l}\text { Basosquamous cell } \\
\text { carcinoma (BSC) }\end{array}$ & $\begin{array}{l}\text { - Unfocused arborizing vessels or serpentine } \\
\text { - BCC dermoscopic traits: ulceration or blood crusts, grey and blue ovoid nests (less visible than in } \\
\text { classic BCC) } \\
\text { - SCC dermoscopic traits: hyperkeratosis, layered keratin masses, surface scale, white structures } \\
\text { (lines, four dots in a square, circles, clods, white homogenous areas), blood spots in keratin mass }\end{array}$ & {$[|2,26,30,3|]$} \\
\hline
\end{tabular}

Abbreviations: BCC, Basal Cell Carcinoma; BSC, Basosquamous Cell Carcinoma.

invasive cancer. Its three-phase nature with the phases of proliferation (early, growth), stabilization (well developed) and regression led to the concept of mimicking by the KA hair cycle. ${ }^{36,37}$ Rosendahl et al identified several dermoscopic criteria that help distinguish keratoacanthoma (KA) and SCC from other non-pigmented lesions, including BCC, actinic keratosis and Bowen's disease. ${ }^{38}$ Dermoscopy does not reliably distinguish KA from SCC. Central keratin mass was the single criterion that distinguished keratoacanthoma from SCC, occurring more frequently in KA than SCC. Most keratoacanthomas should be excised since only dermatopathologists can distinguish KA from SCC. ${ }^{38,39}$

According to NCCN Clinical Practice Guidelines in Oncology (NCCN Guidelines ${ }^{\circledR}$ ) of Squamous Cell
Carcinoma, the low-risk, high-risk and very-high-risk groups were differentiated. The high-risk group has an elevated risk of local recurrence; the very-high-risk group has an elevated risk of local recurrence and an elevated risk of metastasis. The lowrisk SCCs are well or moderately differentiated, whereas the high- or very-high-risk SCCs present poor differentiation with acantholytic (adenoid), adenosquamous, metaplastic (carcinosarcomatous) or dysplastic histologic subtype. ${ }^{40}$ In dermoscopy, the SCC image depends on the degree of histological differentiation. Dermoscopic criteria for the different subtypes of SCC are described in Table $6 .{ }^{11,32,36-38,41,42}$

\section{Merkel-Cell Carcinoma}

Merkel-cell carcinoma (MCC) is a rare skin cancer characterized by an asymptomatic course with aggressive 
Table 4 Clinical Grades and Dermoscopic Patterns of Actinic Keratosis ${ }^{35}$

\begin{tabular}{|l|l|l|}
\hline Grade & Clinical & Dermoscopy \\
\hline $\mathbf{1}^{\circ}$ & Slightly palpable AK (better felt than seen) & Red pseudonetwork pattern, discrete white scales \\
\hline $2^{\circ}$ & Moderately thick AK (easily felt and seen) & Erythematous background \\
\cline { 3 - 3 } & & White to yellow, keratotic and enlarged follicular openings ("strawberry pattern") \\
\hline $3^{\circ}$ & Very thick, hyperkeratotic AK & Scaly and white-yellow-appearing background \\
\cline { 3 - 3 } & & Enlarged follicular openings filled with keratotic plugs \\
\cline { 3 - 3 } & & Structureless white-yellow areas \\
\hline
\end{tabular}

growth and a high tendency for local recurrence and metastases. Approximately $40 \%$ of patients is developing metastasis in distant organs like lymph nodes, lung, liver, adrenals. $^{43}$ It is more often observed in men, over 50 -yearold, with immunosuppression or diseases associated with immunodeficiency. $^{32,44}$ It can be also associated with infection with Merkel-cell polyomavirus (MCPyV) and/ or exposure to ultraviolet radiation. ${ }^{32}$ Most common clinical manifestation is a cherry-red tumour or hard skin infiltration with smooth surface localised commonly on the head or neck. Extremities and trunk are less common localizations. MCC is misdiagnosed as a benign lesion or dermatofibrosarcoma protuberans, cutaneous lymphoma, amelanotic melanoma, angiosarcoma, other primary skin sarcomas, complicated vascular malformations, skin metastases of internal malignancies. ${ }^{4,45}$ The dermoscopic features are not very specific for MCC. In literature milkyred areas, polymorphous, linear irregular and arborizing vessels, structureless areas, white shiny streaks and

Table 5 Differential Diagnosis of Squamous Cell Carcinoma ${ }^{32}$

\begin{tabular}{|l|}
\hline Differential Diagnosis of Squamous Cell Carcinoma \\
\hline Common warts \\
Genital warts \\
Seborrheic keratosis \\
Keratoacanthoma \\
Basal cell carcinoma \\
Actinic keratosis \\
Amelanotic melanoma \\
Adnexal tumours of: \\
- Hair follicles \\
- Sweat glands \\
Atypical fibroxanthoma \\
Skin metastases
\end{tabular}

architectural disorder are described. The dermoscopic picture can be similar in extramammary Paget disease, Bowen disease, SCC, BCC, amelanotic melanoma, dermatofibrosarcoma protuberans and skin metastases. ${ }^{43,46-48}$ In MCC pigmentation is absent and it can be a helpful feature in distinguishing MCC from hypomelanotic melanoma, $\mathrm{BCC}$ or SCC. In these cancers, pigmentation is not clinically visible, but is observed by dermoscopy. ${ }^{43}$

\section{Dermatofibrosarcoma Protuberans}

Dermatofibrosarcoma protuberans (DFSP) is a slowly growing, asymptomatic, fibrohistiocytic tumour. It is locally aggressive with a high recurrence rate. The most common clinical picture of DFSP is an indurated plaque or nodule with reddish brown colour located on the trunk or proximal extremities. $^{49-51}$ It is observed among women 1.14 times more frequently than in men. The peak age at onset is between 20 and 50 years. ${ }^{52,53}$ DFSP may present as a morphea-like, atrophic, sclerotic, violaceous plaque that may ulcerate. ${ }^{54}$ In the differential diagnosis melanoma, cutaneous metastatic carcinomas, dermatofibromas, hypertrophic scars, and keloids can be taken in the consideration. $^{54}$ In the histopathological examination DFSP is classified as spindle cell tumour-like dermatofibroma, malignant fibrous histiocytoma, atypical fibroxanthoma, desmoplastic melanoma, Kaposi sarcoma, and solitary fibrous tumour. However, the infiltrative pattern of DFSP, described as the honeycomb pattern, helps to differentiate it from benign entities. Sometimes diagnosis must be confirmed by immunohistochemistry - DFSP is CD34(+), S100 protein (-), factor XIIIA (-), and desmin (-). ${ }^{49-51}$ In dermoscopic examination delicate pigmented network, unfocused and/or focused arborizing vessels, structureless light brown areas, shiny white streaks, pink background 
Table 6 Dermoscopic Features of Squamous Cell Carcinoma (SCC) and Keratoacanthoma

\begin{tabular}{|c|c|c|}
\hline Disease & Characteristic Dermoscopic Structures & References \\
\hline $\begin{array}{l}\text { SCC in situ/ intraepidermal carcinoma } \\
\text { (IEC) /Bowen's disease }\end{array}$ & $\begin{array}{l}\text { - Erythematous background } \\
\text { - Dotted and glomerular vessels, in clusters } \\
\text { - White, structureless areas } \\
\text { - White scales } \\
\text { - Yellowish homogenous keratin masses } \\
\text { - Microerosions }\end{array}$ & {$[32,36,42]$} \\
\hline $\begin{array}{l}\text { SCC in situ/ intraepidermal carcinoma } \\
\text { (IEC)/Bowen's disease - pigmented }\end{array}$ & $\begin{array}{l}\text { - Glomerular vessels } \\
\text { - Brown or grey granules demonstrating the linear distribution } \\
\text { - Small brown globules, regularly packed in a patchy distribution } \\
\text { - Grey to brown homogeneous pigmentation }\end{array}$ & {$[32,36,42]$} \\
\hline Well differentiated SCC & $\begin{array}{l}\text { - Pink areas distributed relatively even around the periphery of the lesion } \\
\text { - Numerous irregular linear, large-diameter vessels, reduced incidence of } \\
\text { - branching and serpentine vessel forms and fewer vessel types } \\
\text { - White perivascular halos } \\
\text { - White perifollicular circles } \\
\text { - Yhite structureless areas } \\
\text { - Yellowish exfoliation in the centre }\end{array}$ & {$[I I, 32,36,41,42]$} \\
\hline Moderately differentiated SCC & $\begin{array}{l}\text { - Yellow-reddish background } \\
\text { - Pink areas central and in irregular spatial arrangement } \\
\text { - Numerous polymorphic large-diameter vessels } \\
\text { - Yellowish structureless masses with numerous hemorrhages } \\
\text { - Large ulceration in the centre, filled with a keratinous mass } \\
\text { - White ring-type structures }\end{array}$ & {$[11,32,36,41,42]$} \\
\hline Poorly differentiated SCC & $\begin{array}{l}\text { - The predominance of red areas } \\
\text { - Pink areas central and in irregular spatial arrangement } \\
\text { - Numerous polymorphic vessels in more than } 50 \% \text { of the lesion surface } \\
\text { - Diffuse distribution of vessels } \\
\text { - Vessels without white perivascular halos } \\
\text { - Erosion and ulceration } \\
\text { - Absence of scaling and keratin or other white-colored criteria }\end{array}$ & {$[I I, 32,36,41,42]$} \\
\hline Keratoacanthoma & $\begin{array}{l}\text { - Concentric circles of the central crater, surrounded by an ivory white area } \\
\text { - } \text { and adjacent peripheral vessels } \\
\text { - White circles and white structureless areas } \\
\text { - Keratin crust/scale } \\
\text { - Blood spots }\end{array}$ & {$[36-38]$} \\
\hline
\end{tabular}

coloration, and structureless hypo- or depigmented areas were observed. $^{50,55}$

\section{Melanoma}

Melanoma is a malignant tumour originating from neuroectodermal melanocytic cells. Exposure to UV and sunburns are among the most important risk factors for developing melanoma. Melanocytic lesions, especially multiple nevi ( $>50$ nevi) are another risk factor. The risk of developing melanoma increases in people with a family history of melanoma, genetic predisposition (eg, familial atypical mole syndrome - FAMS) and in immunocompromised patients. ${ }^{56}$

Melanoma classification is based on characteristic clinical and histopathological features. There are 4 main subtypes of melanoma: superficial spreading melanoma (60$70 \%$ of cases in Caucasian individuals), nodular melanoma (15-30\%), melanoma developing in lentigo maligna (5$15 \%)$, and acral melanoma $(5-10 \%) .^{57}$ 
Table 7 Dermoscopic Features of Melanoma Varieties

\begin{tabular}{|c|c|c|}
\hline Disease & Characteristic Dermoscopic Structures & References \\
\hline Melanoma in situ & $\begin{array}{l}\text { - Atypical network } \\
\text { - Regression }>50 \% \text { of the lesion surface } \\
\text { - Irregular hyperpigmented areas } \\
\text { - Prominent skin markings } \\
\text { - Angulated lines }\end{array}$ & {$[58,63]$} \\
\hline Spitzoid melanoma & $\begin{array}{l}\text { - Asymmetrically distributed structures (streaks, pseudopods) } \\
\text { - Inverse network } \\
\text { - Atypical vessels }\end{array}$ & {$[11,59,64]$} \\
\hline Nevoid melanoma & $\begin{array}{l}\text { - Multicomponent pattern } \\
\text { - Polymorphic vessels }\end{array}$ & {$[11]$} \\
\hline Verrucous melanoma & $\begin{array}{l}\text { - Blue-white veil } \\
\text { - Pseudopods } \\
\text { - Irregular streaks } \\
\text { - Atypical network } \\
\text { - Blue-black sign } \\
\text { - About } 20 \% \text { of melanomas have features typical of seborrheic keratosis }\end{array}$ & [65] \\
\hline Regressive melanoma & $\begin{array}{l}\text { - White scar-like depigmentation } \\
\text { - Blue/grey granules/peppering }\end{array}$ & {$[\mathrm{II}]$} \\
\hline Amelanotic melanoma & - Usually featureless & {$[11,66]$} \\
\hline
\end{tabular}

Advances in melanoma diagnostics associated with dermoscopy, video-dermoscopy, and increased awareness of melanoma in society have led us to the urge of detecting melanoma in a pre-invasive stage. Therefore, it was decided to verify the dermoscopic criteria for melanoma diagnosis. The introduced changes allow for the diagnosis of pre-invasive tumours, but they are less specific because atypical nevi may have one or more early melanoma criteria. $^{58}$

Melanoma and pigmented nevi have several similar dermoscopic criteria, and the main difference is their asymmetrical or symmetrical distribution, respectively (eg, regular network and irregular network, regular globules and irregular globules, etc.). Therefore, the melanoma that does not have specific dermoscopic criteria can be classified as a nevus.

In the dermoscopic diagnosis of melanoma, one uses scales of different sensitivity and specificity. A 3-point checklist, proposed in 2001 as part of Consensus Net Meeting, includes asymmetry of colour and structure, atypical pigment network and the presence of blue-white structures (blue and white veil and regression areas). Finding 2 of the above criteria gives a high probability of melanoma. ${ }^{59}$ This checklist is characterized by high sensitivity but low specificity.

Another algorithm includes a 7-point checklist. It involves recognizing seven characteristics for melanoma criteria, classified as major or minor. The major criteria are: atypical pigment network, white-blue veil, atypical vascular pattern, minor criteria are: irregular streaks, regression structures, structureless pigmented areas, irregular dots/globules. The presence of one of the three major dermoscopic features of melanoma is assessed as 2 points, the presence of one of the four minor features is assessed as 1 point. In the classic 7-point checklist, the excision threshold was 3 points. ${ }^{60}$ In 2011 Argenziano et al proposed a revised version of the 7-point checklist. Each of the features listed above received a value of 1 point, and the cut-out threshold was 1 point. A revised checklist, with a reduced excision threshold, can be used to increase the sensitivity of early melanoma detection, often indistinguishable from benign lesions. ${ }^{61}$ Unfortunately, the above criteria are insufficient to diagnose melanoma in the earliest phase, melanoma in situ. Melanoma in situ is often recognized as a dysplastic nevus. Usually, at this stage of melanoma, typical dermoscopic diagnostic criteria are 
absent. ${ }^{62}$ Many studies show that only atypical network and regression are present in melanoma in situ. ${ }^{58,63} \mathrm{In}$ a study by Lallas et al, melanoma in situ images were compared with other lesions (atypical nevus, typical nevus, seborrheic keratosis, solar lentigo, lichen planuslike keratosis, BCC, Bowen's disease, invasive melanoma) and additional melanoma in situ indicators were identified: atypical network, extensive regression, and angulated lines. It has been shown that irregular hyperpigmented areas, prominent skin markings and angulated lines were more common in melanomas in situ than in atypical nevi. Regression covering more than $50 \%$ of the lesion surface was associated with $4.7 \times$ more likely melanoma. A new dermoscopic melanoma in situ feature, described as irregular hyperpigmented areas, was also presented. They are dark brown or black small areas visible in the middle parts of the lesion. Their shape is irregular and does not match any known geometric shape (eg, triangle, line, square); therefore, they cannot be classified as any other previously known feature (eg, dots, globules, blotches, lines). Prominent skin markings were the second strong indicator of melanoma in situ compared to atypical nevi. This term has recently been introduced to describe the presence of linear intersecting furrows, lighter than the general lesion pigmentation, mainly seen in melanomas located on the limbs. Angulated lines have been described as a feature observed in melanomas with a lentiginous growth pattern, usually on sun-damaged skin. The presence of angular lines was associated with a 2.2-fold probability of melanoma. ${ }^{58}$

Nevoid melanoma is a rare melanoma subtype that clinically and histopathologically exhibits nevus features. It usually develops in the elderly. Dermoscopy can lead to the diagnosis of naevoid melanoma because some of them show the presence of a multicomponent pattern. In addition, it may be helpful to determine the presence of polymorphic vessels instead of "comma vessels", more typical for dermal nevus. ${ }^{11}$

Morphologically spitzoid melanoma has features of the Spitz/Reed nevus. The "starburst" pattern is described in Reed nevus - dark brown, black or blue centre and symmetrically distributed peripheral streaks or pseudopods. The pigmented Spitz nevus is characterized by the occurrence of symmetrically distributed globules and white spaces between them, the so-called inverse network pattern. Non-pigmented Spitz nevi are characterized by symmetrically distributed dotted vessels with white spaces between them. Structures are symmetrically distributed in the aforementioned patterns. ${ }^{64}$ Otherwise, the same structures (streaks, pseudopods, vessels, inverse network) nonsymmetrically distributed represent melanoma criteria. ${ }^{11}$

Sometimes melanoma may have a verrucous surface due to hyperkeratosis and epidermal hyperplasia, reminiscent of seborrheic keratosis - verrucous melanoma. Most seborrheic keratosis-like melanomas can be correctly diagnosed by dermoscopy. Characteristic criteria of melanoma are present in the dermoscopic examination (blue-white veil, pseudopods, streaks, atypical network and the blueblack sign), however, in about $20 \%$ of melanomas, features typical of SK are present, and the only strong predictor of melanoma is the blue-black sign. ${ }^{65}$

In regressive melanoma, white scar-like depigmented areas and blue/grey granules/peppering occur in regression. These structures suggest a regression process that may also be present in the nevus in regression or LPLK. The correct diagnosis can be made when part of the primary lesion is still present. If the regression processes are more advanced, the diagnosis can be made only based on the histopathological examination of the lesion. ${ }^{11}$

Amelanotic melanoma is the most important trap for clinicians. Although amelanotic melanoma is regularly featureless, it rarely shows a pattern suggesting a benign lesion. The main false-negative diagnosis is pyogenic granuloma, therefore it is suggested that the diagnosis of pyogenic granuloma should be confirmed histopathologically. ${ }^{11,66}$ The most important features of the mentioned melanoma types are summarised in Table $7 .{ }^{11,58,59,63-66}$

\section{Conclusions}

1. Dermoscopy is useful in diagnosing pigmented, as well as non-pigmented, inflammatory, infectious (parasitic) lesions.

2. During medical examinations, it is necessary to assess the patient's entire skin and pay special attention to changes that differ in appearance from others.

3. Many features described in dermoscopy examination can be shared by different skin cancers. In the malignancy pattern, most common features include: polymorphic vessels, especially arborizing and linear irregular vessels; architectural disorder, defined as asymmetrical distribution of different geometric structures in one lesion; red-to-pink structureless areas with a whitish hue; and blue-grey structures. 
4. The most important tips for melanoma diagnosis: melanoma in situ - irregular hyperpigmented areas, naevoid melanoma - history of lesion growth, spitzoid melanoma - patient's age, verrucous melanoma - blue-black signs, regressive melanoma peppering and scar-like depigmentation areas, amelanotic melanoma - pink colour, irregular linear vessels and dotted vessels.

5. Any rapidly growing tumour with polymorphous vessels presents malignancy pattern and should be immediately excised.

6. Knowledge of dermoscopic and histologic correlation in different types of BCC and SCC help with an early diagnosis, shorten the time of recognition and has a significant influence on choosing an appropriate therapeutic method and way of supervising a patient.

7. Dermoscopy may be helpful in diagnostics, however, histopathological examination is crucial for the final diagnosis.

\section{Ethics and Consent}

Ethical approval for this study was obtained from the Ethics Committee of Medical University of Lublin, Poland (KE0254/187/2017). Both patients provided informed consent for the case details and images to be published.

\section{Funding}

This research did not receive any specific grant from funding agencies in the public, commercial, or not-forprofit sectors.

\section{Disclosure}

The authors reported no conflicts of interest for this work.

\section{References}

1. Nakamura H, Hirota S, Adachi S, Ozaki K, Asada H, Kitamura Y. Clonal nature of seborrheic keratosis demonstrated by using the polymorphism of the human androgen receptor locus as a marker. $J$ Invest Dermatol. 2001;116(4):506-510. doi:10.1046/j.15231747.2001.01289.x

2. Nakagawa K, Yamamura K, Maeda S, Ichihashi M. bcl-2 expression in epidermal keratinocytic diseases. Cancer. 1994;74(6):1720-1724. doi:10.1002/1097-0142(19940915)74:6<1720::AIDCNCR2820740613>3.0.CO;2-T

3. Hafner C, Toll A, Fernández-Casado A, et al. Multiple oncogenic mutations and clonal relationship in spatially distinct benign human epidermal tumours. Proc Natl Acad Sci U S A. 2010;107 (48):20780-20785. doi:10.1073/pnas.1008365107

4. Simionescu O, Popescu BO, Costache M, et al. Apoptosis in seborrheic keratoses: an open door to a new dermoscopic score. $J$ Cell Mol Med. 2012;16(6):1223-1231. doi:10.1111/j.1582-4934.2012.01558.x
5. Teraki E, Tajima S, Manaka I, Kawashima M, Miyagishi M, Imokawa G. Role of endothelin-1 in hyperpigmentation in seborrhoeic keratosis. Br J Dermatol. 1996;135(6):918-923. doi:10.1046/ j.1365-2133.1996.d01-1095.x

6. Cimpean I, Theate I, Vanhooteghem O. Seborrheic keratosis evolution into squamous cell carcinoma: a truly modified sun-related tumour? A case report and review of the literature. Dermatol Rep. 2019;11(1):7999. doi:10.4081/dr.2019.7999

7. Squillace L, Cappello M, Longo C, Moscarella E, Alfano R, Argenziano G. Unusual dermoscopic patterns of seborrheic keratosis. Dermatology. 2016;232(2):198-202. doi:10.1159/000442439

8. Wollina U. Recent advances in managing and understanding seborrheic keratosis. F1000Res. 2019;8:1520. doi:10.12688/ f1000research.18983.1

9. Kamińska-Winciorek G. Dermoskopia jako metoda diagnostyczna wybranych chorób skóry. In: Adamski Z, Kaszuba A, editors. Metody Diagnostyczne w Dermatologii, Wenerologii I Mikologii Lekarskiej. Lublin: Czelej; 2015:111-125.

10. Gülseren D, Hofmann-Wellenhof R. Evaluation of dermoscopic criteria for seborrheic keratosis on non-polarized versus polarized dermoscopy. Skin Res Technol. 2019;25(6):801-804. doi:10.1111/ srt. 12721

11. Papageorgiou V, Apalla Z, Sotiriou E, et al. The limitations of dermoscopy: false positive and false negative tumours. J Eur Acad Dermatol Venereol. 2018;32(6):879-888. doi:10.1111/jdv.14782

12. Bowling J. Dermoskopia Diagnostyczna. Przewodnik Ilustrowany. Kamińska-Winciorek G (Red.). Lublin: Czelej; 2018.

13. Lin J, Han S, Cui L, et al. Evaluation of dermoscopic algorithm for seborrhoeic keratosis: a prospective study in 412 patients. J Eur Acad Dermatol Venereol. 2014;28:957-962. doi:10.1111/jdv.12241

14. Minagawa A. Dermoscopy-pathology relationship in seborrheic keratosis. $J$ Dermatol. 2017;44(5):518-524. doi:10.1111/13468138.13657

15. Zalaudek I, Kreusch J, Giacomel J, et al. How to diagnose nonpigmented skin tumours: a review of vascular structures seen with dermoscopy: part II. Nonmelanocytic skin tumours. J Am Acad Dermatol. 2010;63:. doi:10.1016/j.jaad.2009.11.697

16. Chung E, Marghoob AA, Carrera C, Marchetti MA. Clinical and dermoscopic features of cutaneous melanoacanthoma. JAMA Dermatol. 2015;151(10):1129-1130. doi:10.1001/jamadermatol.2015.1453

17. Longo C, Zalaudek I, Moscarella E, et al. Clonal seborrheic keratosis: dermoscopic and confocal microscopy characterization. $J$ Eur Acad Dermatol Venereol. 2014;28(10):. doi:10.1111/jdv.12261

18. Ramyead S, Diaz-Cano SJ, Pozo-Garcia L. Dermoscopy of clonal seborrheic keratosis. J Am Acad Dermatol. 2015;73(2):e47-e49. doi:10.1016/j.jaad.2015.04.013

19. Watanabe S, Sawada M, Dekio I, Ishizaki S, Fujibayashi M, Tanaka M. Chronology of lichen planus-like keratosis features by dermoscopy: a summary of 17 cases. Dermatol Pract Concept. 2016;6(2):29-35. doi:10.5826/dpc.0602a06

20. Liopyris K, Navarrete-Dechent C, Dusza SW, et al. Clinical and dermoscopic features associated with lichen planus-like keratoses that undergo skin biopsy: a single-centre, observational study. Australas J Dermatol. 2019;60(2):e119-e126. doi:10.1111/ ajd.12955

21. Sisti A, Fallaha A, Tassinari J, Nisi G, Grimaldi L, Eisendle K. Melanoma in situ mimicking a lichen planus-like keratosis. Acta Biomed. 2018;88(4):496-498. doi:10.23750/abm.v88i4.5699

22. Apalla Z, Lallas A, Sotiriou E, Lazaridou E, Ioannides D. Epidemiological trends in skin cancer. Dermatol Pract Concept. 2017;7(2):1-6. doi:10.5826/dpc.0702a01

23. Lesiak A, Slowik-Rylska M, Rogowski-Tylman M, SysaJedrzejowska A, Norval M, Narbutt J. Risk factors in Central Poland for the development of superficial and nodular basal cell carcinomas. Arch Med Sci. 2010;6(2):270-275. doi:10.5114/ aoms.2010.13907 
24. Rubin AI, Chen EH, Ratner D. Basal-cell carcinoma. $N$ Engl $J$ Med. 2005;353(21):2262-2269. doi:10.1056/NEJMra044151

25. Ciążyńska M, Narbutt J, Woźniacka A, Lesiak A. Trends in basal cell carcinoma incidence rates: a 16-year retrospective study of a population in central Poland. Postepy Dermatol Alergol. 2018;35 (1):47-52. doi:10.5114/ada.2018.73164

26. Lesiak A, Czuwara J, Kamińska-Winciorek G, et al. Basal cell carcinoma. Diagnostic and therapeutic recommendations of the polish dermatological society rak podstawnokomórkowy skóry. Rekomendacje diagnostyczno-terapeutyczne Polskiego Towarzystwa Dermatologicznego Dermatol Rev. Przegl Dermatol. 2019;106:107-126. doi:10.5114/dr.2019.85572

27. Schmults CD, Blitzblau R, Aasi SZ, et al. Basal cell skin cancer, NCCN clinical practice guidelines in oncology, Version 2.2021. 2021. Available from: www.nccn.org. Accessed June 7, 2021.

28. Husein-ElAhmed H. Sclerodermiform basal cell carcinoma: how much can we rely on dermatoscopy to differentiate from non-aggressive basal cell carcinomas? Analysis of 1256 cases. An Bras Dermatol. 2018;93(2):229-232. doi:10.1590/abd18064841.20186699

29. Wozniak-Rito A, Zalaudek I, Rudnicka L. Dermoscopy of basal cell carcinoma. Clin Exp Dermatol. 2018;43(3):241-247. doi:10.1111/ ced. 13387

30. Giacomel J, Lallas A, Argenziano G, et al. Dermoscopy of basosquamous carcinoma. Br J Dermatol. 2013;169(2):358-364. doi:10.1111/ bjd. 12394

31. Akay BN, Saral S, Heper AO, Erdem C, Rosendahl C. Basosquamous carcinoma: dermoscopic clues to diagnosis. J Dermatol. 2017;44(2):127-134. doi:10.1111/1346-8138.13563

32. Lesiak A, Czuwara J, Kamińska-Winciorek G, et al. Squamous cell carcinoma and Merkel-cell carcinoma. Diagnostic and therapeutic recommendations of the polish dermatological society. Rak kolczystokomórkowy skóry i rak z komórek Merkla. Rekomendacje diagnostyczno-terapeutyczne Polskiego Towarzystwa Dermatologicznego Dermatol Rev. Przegl Dermatol. 2019;106:127-149. doi:10.5114/dr.2019.85573

33. Manfredini M, Longo C, Ferrari B, et al. Dermoscopic and reflectance confocal microscopy features of cutaneous squamous cell carcinoma. J Eur Acad Dermatol Venereol. 2017;31(11):1828-1833. doi:10.1111/jdv.14463

34. Bartosińska J, Gerkowicz A, Niewiedzioł M, Szczepanik-Kułak P, Kwaśny M, Krasowska D. Application of photodynamic therapy with the use of superluminescent light-emitting diode (sLED) lamp in actinic keratosis. Dermatol Rev. 2019;106:372-383. doi:10.5114/ dr.2019.88254

35. Zalaudek I, Piana S, Moscarella E, et al. Morphologic grading and treatment of facial actinic keratosis. Clin Dermatol. 2014;32 (1):80-87. doi:10.1016/j.clindermatol.2013.05.028

36. Warszawik-Hendzel O, Olszewska M, Maj M, Rakowska A, Czuwara J, Rudnicka L. Non-invasive diagnostic techniques in the diagnosis of squamous cell carcinoma. J Dermatol Case Rep. 2015;9 (4):89-97. doi:10.3315/jdcr.2015.1221

37. Kwiek B, Schwartz RA. Keratoacanthoma (KA): an update and review. J Am Acad Dermatol. 2016;74(6):1220-1233. doi:10.1016/j. jaad.2015.11.033

38. Rosendahl C, Cameron A, Argenziano G, Zalaudek I, Tschandl P, Kittler H. Dermoscopy of squamous cell carcinoma and keratoacanthoma. Arch Dermatol. 2012;148(12):1386-1392. doi:10.1001/archdermatol.2012.2974

39. Lin MJ, Pan Y, Jalilian C, Kelly JW. Dermoscopic characteristics of nodular squamous cell carcinoma and keratoacanthoma. Dermatol Pract Concept. 2014;4(2):9-15. doi:10.5826/dpc.0402a02

40. Schmults CD, Blitzblau R, Aasi SZ, et al. Squamous cell skin cancer, NCCN clinical practice guidelines in oncology, version 1.2021. 2021. Available from: www.nccn.org. Accessed June 7, 2021.)
41. Pyne J, Sapkota D, Wong JC. Squamous cell carcinoma: variation in dermatoscopic vascular features between well and non-well differentiated tumours. Dermatol Pract Concept. 2012;2(4):204a05. doi: $10.5826 / \mathrm{dpc} .0204 \mathrm{a} 05$

42. Zalaudek I, Giacomel J, Schmid K, et al. Dermatoscopy of facial actinic keratosis, intraepidermal carcinoma, and invasive squamous cell carcinoma: a progression model. J Am Acad Dermatol. 2012;66 (4):589-597. doi:10.1016/j.jaad.2011.02.011

43. Zalaudek I, Argenziano G, Giacomel J. Dermatoscopy of NonPigmented Skin Tumors: Pink-Think-Blink. Boca Raton: CRC Press Taylor \& Francis Group; 2015.

44. Schmults CD, Blitzblau R, Aasi SZ, et al. Merkel cell carcinoma, NCCN clinical practice guidelines in oncology, version 1.2021. 2021. Available from: www.ncen.org. Accessed June 7, 2021.

45. Heath M, Jaimes N, Lemos B, et al. Clinical characteristics of Merkel cell carcinoma at diagnosis in 195 patients: the AEIOU features. J Am Acad Dermatol. 2008;58:375-381. doi:10.1016/j. jaad.2007.11.020

46. Navarrete-Dechent C, Cordova M, Aleissa S, et al. Dermoscopy and reflectance confocal microscopy of intraepidermal Merkel cell carcinoma. Australas J Dermatol. 2020.

47. Jalilian C, Chamberlain JU, Haskett M, et al. Clinical and dermoscopic characteristics of Merkel cell carcinoma. Br J Dermatol. 2013;169:294-297. doi:10.1111/bjd.12376

48. Harting M, Ludgate M, Fullen D, Johnson T, Bichakjian CH. Dermatoscopic vascular patterns in cutaneous Merkel cell carcinoma. J Am Acad Dermatol. 2012;66:923-927. doi:10.1016/j. jaad.2011.06.020

49. Li Y, Wang C, Xiang B, Shen S, Li L, Ji Y. Clinical features, pathological findings and treatment of recurrent dermatofibrosarcoma protuberans. J Cancer. 2017;8(7):1319-1323. doi:10.7150/jca.17988

50. Escobar GF, Ribeiro CK, Leite LL, Barone CR, Cartell A. Dermoscopy of dermatofibrosarcoma protuberans: what do we know? Dermatol Pract Concept. 2019;9(2):139-145. doi:10.5826/ dpc.0902a10

51. Thway K, Noujaim J, Jones RL, Fisher C. Dermatofibrosarcoma protuberans: pathology, genetics, and potential therapeutic strategies. Ann Diagn Pathol. 2016;25:64-71. doi:10.1016/j. anndiagpath.2016.09.013

52. Kreicher KL, Kurlander DE, Gittleman HR, Barnholtz-Sloan JS, Bordeaux JS. Incidence and survival of primary dermatofibrosarcoma protuberans in the United States. Dermatol Surg. 2016;42(Suppl 1): S24-S31. doi:10.1097/DSS.0000000000000300

53. Criscito MC, Martires KJ, Stein JA. Prognostic factors, treatment, and survival in dermatofibrosarcoma protuberans. JAMA Dermatol. 2016;152(12):1365-1371. doi:10.1001/ jamadermatol.2016.1886

54. Costa C, Cappello M, Argenziano G, Piccolo V, Scalvenzi M. Dermoscopy of uncommon variants of dermatofibrosarcoma protuberans. J Eur Acad Dermatol Venereol. 2017;31(8):e366-e368. doi:10.1111/jdv.14167

55. Bernard J, Poulalhon N, Argenziano G, et al. Dermoscopy of dermatofibrosarcoma protuberans: a study of 15 cases. Br J Dermatol. 2013;169(1):85-90. doi:10.1111/bjd.12318

56. Rutkowski P, Wysocki PJ, Nowecki ZI, et al. Czerniaki skóry zasady postępowania diagnostyczno-terapeutycznego w 2013 roku. Cutaneous melanoma - diagnostic and therapeutic guidelines in 2013. Przegl Dermatol. 2013;100:1-15.

57. Jaimes N, Marghoob AA, Rabinovitz H, et al. Clinical and dermoscopic characteristics of melanomas on nonfacial chronically sun-damaged skin. J Am Acad Dermatol. 2015;72(6):1027-1035. doi:10.1016/j.jaad.2015.02.1117

58. Lallas A, Longo C, Manfredini M, et al. Accuracy of dermoscopic criteria for the diagnosis of melanoma in situ. JAMA Dermatol. 2018;154(4):414-419. doi:10.1001/jamadermatol.2017.6447 
59. Argenziano G, Soyer HP, Chimenti S, et al. Dermoscopy of pigmented skin lesions: results of a consensus meeting via the internet. $J \mathrm{Am}$ Acad Dermatol. 2003;48(5):679-693. doi:10.1067/mjd.2003.281

60. Argenziano G, Fabbrocini G, Carli P, De Giorgi V, Sammarco E, Delfino M. Epiluminescence microscopy for the diagnosis of doubtful melanocytic skin lesions. Comparison of the $\mathrm{ABCD}$ rule of dermatoscopy and a new 7-point checklist based on pattern analysis. Arch Dermatol. 1998;134(12):1563-1570. doi:10.1001/ archderm.134.12.1563

61. Argenziano G, Catricalŕ C, Ardigo M, et al. Seven-point checklist of dermoscopy revisited. $B r \quad J$ Dermatol. 2011;164(4):785-790. doi:10.1111/j.1365-2133.2010.10194.x

62. Lallas A, Zalaudek I, Apalla Z, et al. Management rules to detect melanoma. Dermatology. 2013;226(1):52-60. doi:10.1159/ 000346645
63. Seidenari S, Ferrari C, Borsari S, et al. Reticular grey-blue areas of regression as a dermoscopic marker of melanoma in situ. $\mathrm{Br}$ $J \quad$ Dermatol. 2010;163(2):302-309. doi:10.1111/j.13652133.2010.09821.x

64. Lallas A, Apalla Z, Ioannides D, et al. Update on dermoscopy of spitz/reed naevi and management guidelines by the international dermoscopy society. $B r \quad J$ Dermatol. 2017;177(3):645-655. doi:10.1111/bjd.15339

65. Carrera C, Segura S, Aguilera P, et al. Dermoscopic clues for diagnosing melanomas that resemble seborrheic keratosis. JAMA Dermatol. 2017;153:544-551. doi:10.1001/jamadermatol.2017.0129

66. Rosendahl C, Cameron A, Tschandl P, et al. Prediction without Pigment: a decision algorithm for non-pigmented skin malignancy. Dermatol Pract Concept. 2014;4(1):59-66. doi:10.5826/dpc.0401a09

\section{Publish your work in this journal}

Clinical, Cosmetic and Investigational Dermatology is an international, peer-reviewed, open access, online journal that focuses on the latest clinical and experimental research in all aspects of skin disease and cosmetic interventions. This journal is indexed on CAS.
The manuscript management system is completely online and includes a very quick and fair peer-review system, which is all easy to use. Visit http://www.dovepress.com/testimonials.php to read real quotes from published authors. 